\title{
Determination of the rockfall source in an urban settlement area by using a rule-based fuzzy evaluation
}

\author{
H. Aksoy and M. Ercanoglu \\ Hacettepe University, Engineering Faculty, Department of Geological Engineering, Applied Geology Division, 06800 \\ Beytepe/Ankara, Turkey
}

Received: 4 July 2006 - Revised: 7 September 2006 - Accepted: 24 October 2006 - Published: 27 October 2006

\begin{abstract}
The evaluation of the rockfall initiation mechanism and the simulation of the runout behavior is an important issue in the prevention and remedial measures for potential rockfall hazards in highway protection, in forest preservation, and especially in urban settlement areas. In most of the studies in the literature, the extent of the rockfall hazard was determined by various techniques basing on the selection of a rockfall source, generally defined as zones of rock bodies having slope angles higher than a certain value, proposed by general practice. In the present study, it was aimed to carry out a rule-based fuzzy analysis on the discontinuity data of andesites in the city of Ankara, Turkey, in order to bring a different and rather systematic approach to determine the source areas for rockfall hazard in an urban settlement, based on the discontinuity and natural slope features. First, to obtain rock source areas (RSAs), data obtained from the field studies were combined with a rule-based fuzzy evaluation, incorporating the altitude difference, the number of discontinuities, the number of wedges and the number of potential slides as the parameters of the fuzzy sets. After processing the outputs of the rule-based fuzzy system and producing the linguistic definitions, it could be possible to obtain potential RSAs. According to the RSA maps, $1.7 \%$ of the study area was found to have "high RSA", and $5.8 \%$ of the study area was assigned as "medium RSA". Then, potential rockfall hazard map was prepared. At the final stage, based upon the high and medium RSAs, 3.6\% of the study area showed "high rockfall potential", while areal distribution of "medium rockfall potential" was found as $7.9 \%$. Both RSA and potential rockfall hazard map were in accordance with the observations performed in the field.
\end{abstract}

Correspondence to: M. Ercanoglu

(murate@ hacettepe.edu.tr)

\section{Introduction}

Rockfall is a natural phenomenon that can be defined as the detachment and falling of rock blocks down the slope of a rock body. These blocks may bounce or roll depending on the volume of the mass and the geometry of the rock slope and rock properties. In other respect, the word rockfall is usually used to describe small and rapid phenomena, difficult to predict without any extensive instrumentation, from block falls of a few $\mathrm{dm}^{3}$ up to $10000 \mathrm{dm}^{3}$ events (DussaugePeisser et al., 2002). Initiation of a rockfall event can be sourced from different geological, geomorphologic, climatologic, and/or human-related processes such as change in pore water pressure, freezing and thawing, chemical/physical weathering, road cuts etc. In general, rockfall assessment by relevant parameters are difficult to assess due to its complex nature. Generally, the geometrical and geomechanical properties of the blocks and of the slopes, and the exact location of the rockfall source area (RSA) can not be properly described due to uncertainties (Crosta and Agliardi, 2003). Furthermore, it is difficult to quantify rockfall incidence and provide a general context (Duarte and Marquinez, 2002).

Selection of appropriate parameters, which are not only meaningful, but also necessary for the special cases, is the most important task of any methodology employed. In addition, the difficulties in determining the various types of factors such as the scale of the study, financial conditions, time, and experience may also affect the parameters to be used. Furthermore, it is important to use the resources in the most profitable way to provide methods and concepts which can be applied to gain the most benefit from lowest costs (Glade and Crozier, 2005).

Rockfalls may become a risk when they threaten lives especially in urban areas or close to highways. Thus, evaluation of the mechanism and the information about rockfall events become very important issues for planning, remedial works, and mitigation efforts, particularly for the urban

Published by Copernicus GmbH on behalf of the European Geosciences Union. 


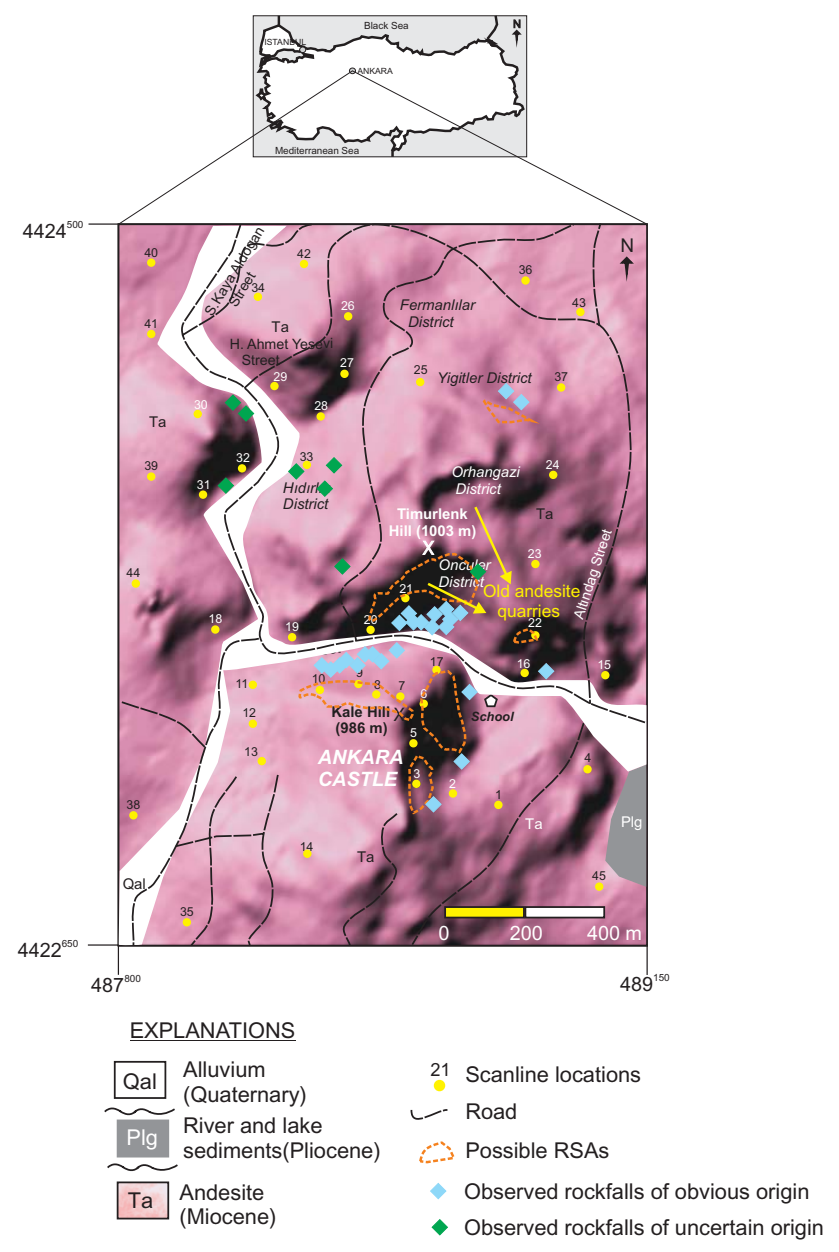

Fig. 1. Geological setting and rockfall inventory map of the study area.

settlement areas. In literature, numerous works were focused on the study of rockfall mechanism in mountainous regions to analyze the risk for highways, or to provide remedial measures for highway protection, forest preservation and mathematical approaches to simulate the runout behavior of the moving mass (e.g. Wieczorek et al., 1998; Baillifard et al., 2003; Guzzetti et al., 2003; Hantz et al., 2003; Jaboyedoff and Labiouse, 2003; Crosta and Agliardi, 2004; Dorren et al., 2004; Petje et al., 2005). Many of these studies were carried out at regional scale and rockfall models were proposed to estimate the extent of significant hazard. However, in almost all studies, the source area for the rockfall was determined either by evaluation based on observations in the field or selecting areas prone to rockfall on various models and assumptions assigning slope angles higher than a certain value based on professional experience (e.g. $60^{\circ}$ in Guzzetti et al., 2003; $37^{\circ}$ in Crosta et al., 2006), which in turn, is closely related to the mesh size of the DEM. In this respect, fractured or jointed rock bodies with steep slope angles were assumed to behave as source for rockfall.
Although there are some studies related to integration of fuzzy logic to general landslide concept (e.g. Chi et al., 2002; Ercanoglu and Gokceoglu, 2002; Gorsevski et al., 2003; Ercanoglu and Gokceoglu, 2004) and hazard or risk management (e.g. Krause et al., 2005), we believe that the present study will contribute to the fuzzy logic related landslide evaluation in terms of rockfall source area determination. In the present study, it was attempted to carry out a rule-based fuzzy analysis on the discontinuity data of andesites in the city of Ankara, Turkey, in order to bring a different approach to determine the source areas for rockfall hazard in an urban settlement based on the discontinuity and natural slope features. To obtain RSAs, data obtained from the field studies were combined with a rule-based fuzzy approach, and, at the final stage, potential rockfall hazard maps were obtained. The crucial points of this study are twofold: (a) determination of RSAs by rule-based fuzzy approach, and (b) providing a potential rockfall hazard map. The authors believe that the preparation of a potential rockfall hazard map in this study satisfies the need for such an issue in the study area, as suggested in the previous works (e.g. Ercanoglu, 1997; Gokceoglu et al., 2000; Ercanoglu and Aksoy, 2004) carried out in the same area.

\section{Presentation of the study area}

The study area, covering about $2.5 \mathrm{~km}^{2}$ in a densely populated zone, is situated in the central part of Ankara, the capital city of Turkey (Fig. 1), It has been the subject of many studies (e.g. Ercanoglu, 1997; Gokceoglu et al., 2000; Ercanoglu and Aksoy, 2004). There are a host of squatters built unconciously in old andesite quarries and historical Ankara Castle. This part of the city is considered as a typical uncontrolled urbanization area. In this part of the city, several rockfall incidences were observed to cause at least material damage to the houses and roads, and threaten from time to time human life. However, there are no reliable rockfall history data. Figures $2 \mathrm{a}, \mathrm{b}$, and $\mathrm{c}$ show the general character of the rock medium in the study area.

The principal rock unit in the area consists of Miocene aged andesites, forming high topographical features with several joint sets developed systematically. Andesites in the study area are generally steeply jointed, and were considered as the products of Miocene volcanism in Central Anatolia (Erol, 1961; Erentoz, 1975). The rock has a rather fresh appearance throughout the area, showing local weathering. Other geological units of minor superficial distribution are Pliocene aged lacustrine deposits and recent alluvium, forming lower altitude morphological features (see Fig. 1).

Although many studies for site selection purposes or particular engineering geological projects regarding the layout of individual structures may require very sensitive maps (e.g. 1:500, 1:1000), many others may adopt smaller scales like 1:5000, 1:10000, 1:25000 etc. for general assessment and 
planning of land use in urban areas. In fact, in literature there exist similar studies on rockfall hazard assessment in urban areas using map scales 1:5000 or smaller (e.g. Agliardi and Crosta, 2003; Ayala-Carcedo et al., 2003). Maps of scale greater than 1:20000 would be acceptable for slope stability studies in sensitive areas, residential planning or hazard zonation (Resources Inventory Committee, 1996). Thus, a DEM (Digital Elevation Model) was prepared from the 1/5000 scaled topographic map of the study area (see Fig. 1). It contains 190 rows and 150 columns on the basis of a $9 \times 9 \mathrm{~m}$ grid base. Topographical elevations range between 850 and $1003 \mathrm{~m}$. The higher elevations form the steep slopes, where the slope angle values reach nearly $90^{\circ}$. The slope angle and slope aspect maps derived from the DEM are given in Figs. 3a and b, respectively. In this figure, the slope angles and the slope aspects (orientations) were calculated on pixel basis using SURFER (Ver. 8) (2002) program to produce the database on slope geometry, which will be used in further analyses.

\section{Discontinuity data}

When dealing with jointed or fractured rock masses, identifying the characteristics of the discontinuities is a very important stage. A detailed discontinuity survey conforming with the ISRM (1981) standards was performed in the area during the years 1996 and 1997 along 36 scanlines; and the database was improved with additional scanlines in 2005 yielding a total number of 2106 discontinuity records along 45 scanlines (see Fig. 1). To determine the major discontinuity sets, 2106 measured discontinuities were plotted and processed using the software DIPS (Diedrics and Hoek, 1989). According to these analyses, six major discontinuity sets were identified in the study area (Fig. 4). The properties of the discontinuities used in the analyses are given in Table 1.

During the field studies, 35 rockfall incidences were mapped based on the field observations and communication with local people. Possible source areas of these rockfall incidences were also mapped during the field studies (see Fig. 1). Nevertheless, some of them could not have been mapped due to the dense settlement in the study area.

Field investigations and related literature (e.g. Karacan and Kasapoglu, 1986; Ercanoglu, 1997; Kasapoglu, 2000; Ercanoglu and Aksoy, 2004) indicated that the types of discontinuities present in the rock unit studied where principally cooling and tectonic types of joints. The cooling joints developed in the rock units generally occur as vertical or near to vertical surfaces with different orientations. On the other hand, the tectonic joints are observed as tension or shear fractures in relation to the tectonic regime that prevailed during the Neogene (Karacan and Kasapoglu, 1986; Kasapoglu, 2000).
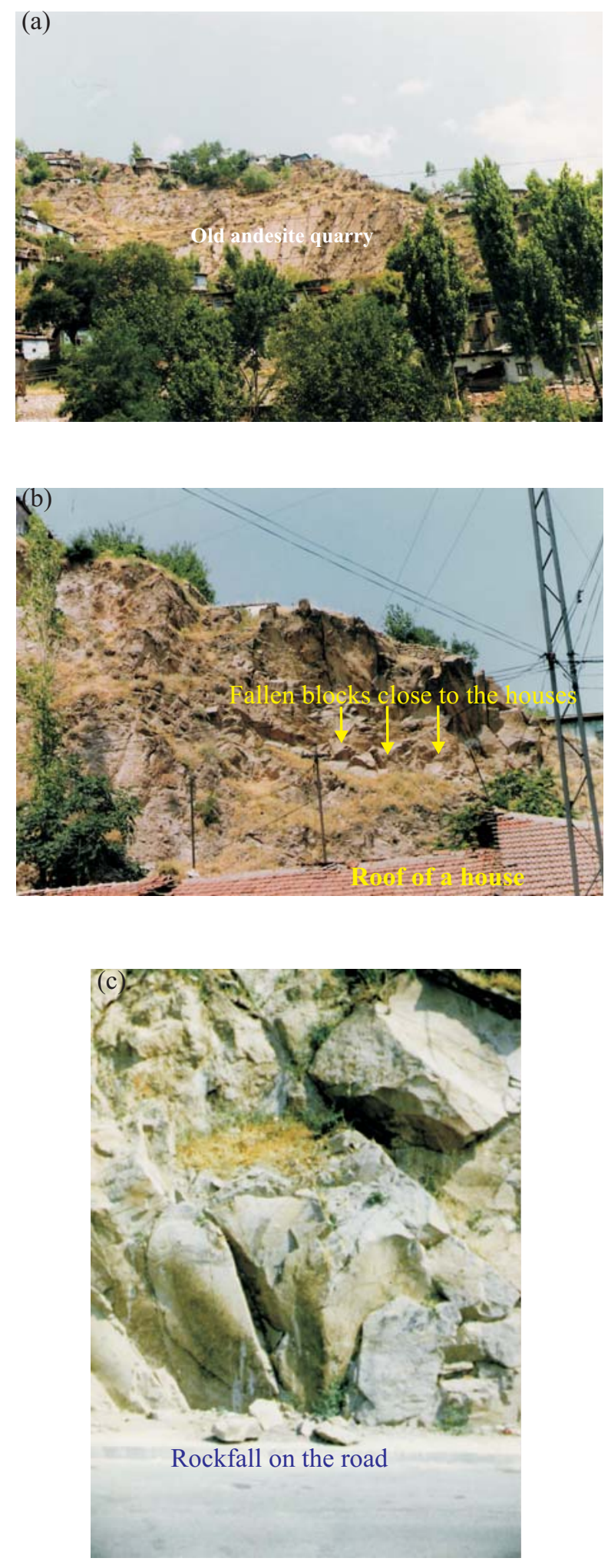

Fig. 2. (a) General view of the Timurlenk Hill and an old andesite quarry, (b) fallen blocks threatening a house, (c) rockfall on a road. 
Table 1. Characteristics of the discontinuities.

\begin{tabular}{ccc}
\hline Discontinuity set & Dip direction/dip $\left(^{\circ}\right)$ & Mean discontinuity spacing $(\mathrm{m})$ \\
\hline 1 & $220 / 75$ & 0.34 \\
2 & $255 / 76$ & 0.39 \\
3 & $321 / 75$ & 0.27 \\
4 & $034 / 79$ & 0.34 \\
5 & $072 / 75$ & 0.36 \\
6 & $061 / 14$ & 0.21 \\
\hline
\end{tabular}

\section{Selection and preparation of the parameters for anal- yses}

When applying any model to assess a natural hazard, it is very important to define the criteria controlling the hazard in concern. Generally, the criteria depend both on real geoenvironmental conditions and the purpose of mapping. In addition, engineering judgment has to be used to establish the real criteria for the real geo-environment (Abdolmasov and Obradovic, 1997). In other words, selection of the parameters or layers in such treatment depends mainly upon engineering judgment and/or expert opinion. This means that it is natural to consider any parameter effective on the problem definition should be taken into account in the definition of the relation between the input(s) and the output(s).

To evaluate rockfall hazard, at the first stage, origin and initiation conditions, provided by RSAs, should be defined and/or mapped. In general, RSAs can be mapped by field work and/or air photo interpretations. With the aid of Geographic Information System (GIS), it became easier to assess and evaluate RSAs since the topographic data can easily be obtained, particularly for regional scale studies. Different data sources which may be effective on rockfall occurrence are available (e.g. slope angle, discontinuity characteristics, curvature, slope scree, distance to faults, block size, block shape etc.). For example, in terms of curvature, slope concavity and convexity influence the velocity and energy losses. With larger slope concavity the runout distance of rockfall is substantially larger (Petje et al., 2005). On the other hand, the presence of slope scree below the rock cliff suggests slope raveling activity, and it can be linked to the progressive failure (Baillifard et al., 2003). As can be seen from these examples, selected parameters and their importance on rockfall event may change from one location to another. In addition, data availability, reliability, and rockfall history (i.e. inventory) become important for the analyses.

Based on the field observations, it was concluded that the rockfall initiation in the present study was completely related to natural slope and discontinuity characteristics in the study area. Along with the rock slope geometry (i.e. slope angle and slope aspect), the authors believe that the presence of discontinuities, their frequency, their capability of forming rock blocks or wedges, and ability to produce movement along the discontinuity surfaces all contributed to the rockfall potential and might have been included in the evaluation to determine the source area for rockfall. Therefore, the following morphological and structural features of the area were adopted as the parameters to be used in the fuzzy evaluation of which the details will be given later in the section devoted to the methodology: (i) altitude difference, (ii) average number of discontinuities, (iii) average number of wedges, (iv) average number of slide potential.

To evaluate the above parameters, the DEM of the study area and the discontinuity database were used, and four different maps were obtained for the parameters cited above. The computer program Matterocking (Version 2.0) (2002), produced by CREALP (Centre de Recherche Sur L'environnement Alpin), was used to produce the parameter maps. It uses the DEM, as a treatment file (slope and slope aspect) and discontinuity characteristics (dip, dip direction, and spacing) for detection of rock slope instabilities. The details can be found in the manual of the software, or on the website (http://www.quanterra.org/softs.HTM).

\section{Methodology}

In literature, various qualitative and quantitative techniques are applied for landslide susceptibility, hazard, and risk assessment (Aleotti and Chowdhury, 1999). In terms of rock slope analyses, conventional (kinematic, limit equilibrium) techniques, numerical (continuum, discontinuum, hybrid) methods and empirical approaches exist (Coggan et al., 1998; Glade and Crozier, 2005). All of the methods may have advantages and limitations as well. For example, conventional limit equilibrium technique can analyze factor of safety sensitivity to changes in slope geometry and material properties. However, well-defined input data are required for reliable evaluation. Numerical models can simulate complex behavior and mechanisms, but the user must be well-trained or experienced (need to be aware of model and software limitations, boundary effects, meshing errors etc.), and they have no ability to model the effects of highly jointed rocks (Coggan et al., 1998). Dorren (2002) states that empirical models may provide quick and simple approximation of rockfall 
runout zones. On the other hand, empirical models make use of available data sets on different processes and therefore are subjected to a high degree of approximation. In fact, it is often difficult to have a complete and satisfactory description of the actual process, geometry, and rock detachment conditions (Crosta et al., 2003). Although rock slope analyses are commonly based on conventional stability analysis techniques, empirical estimates, and more sophisticated numerical methods, it should always be remembered that the more advanced models are, the highest is the input data requirement, and thus, the more complex is the assessment. Hence, empirical and conventional techniques are applied for back analysis or for preliminary assessments. Detailed site-specific investigations require numerical models based on continuum modeling, discontinuum modeling, or hybrid/coupled modeling. The latter models, in particular, are used in mining and civil engineering applications (Glade and Crozier, 2005).

In general, most of the engineering geological problems are complex and exact solutions to these problems rarely exist because the relationships among the variables of the problem(s) are not known exactly due to imprecision and uncertainty (Alvarez-Grima, 2000). In the last two decades, there has been an increasing awareness and utilization of AI (Artificial Intelligence) techniques in engineering geology. The most important reason for this situation may be sourced from the ability of AI techniques to handle imprecise data in engineering geology effectively. A rule-based fuzzy model, one of the most widely used fuzzy modeling techniques, was employed to determine the RSAs in this study.

After introduction of fuzzy set concept by Zadeh (1965), rule-based fuzzy approach (Zadeh, 1973), based on human thinking, emerged to solve complex problems in engineering applications in succeeding years. Fuzzy rules are linguistic descriptions to solve a certain problem using "If-Then" rules, and a way of representing knowledge about the problem considered. A fuzzy rule comprises two different parts as explained below:

If premise (antecedent) Then conclusion (consequent)

This form of expression is referred to the "If-Then" rulebased form, and it expresses a fuzzy interference between antecedent and consequent parts by propositions (Ross, 1995). The existing rule-based models and their main differences were summarized in Table 2. In this study, the Mamdani model (linguistic fuzzy model) was used to determine the RSAs. "If-Then" rule structure of this model was given in the following form:

$R_{i}$ : If $x_{i}$ is $A_{i l}$ and ......and $X_{r}$ is $A_{i r}$ Then $y$ is $B_{i}$,

for $i=1,2, \ldots, k$

where $k$ is the number of rules, $x_{i}(\mathrm{i}=1,2, \ldots, 1)$ are the input variables, $y$ is the output variable. The schematic representation and process units were given in Fig. 5. The other important concepts about Mamdani model can be found in detail
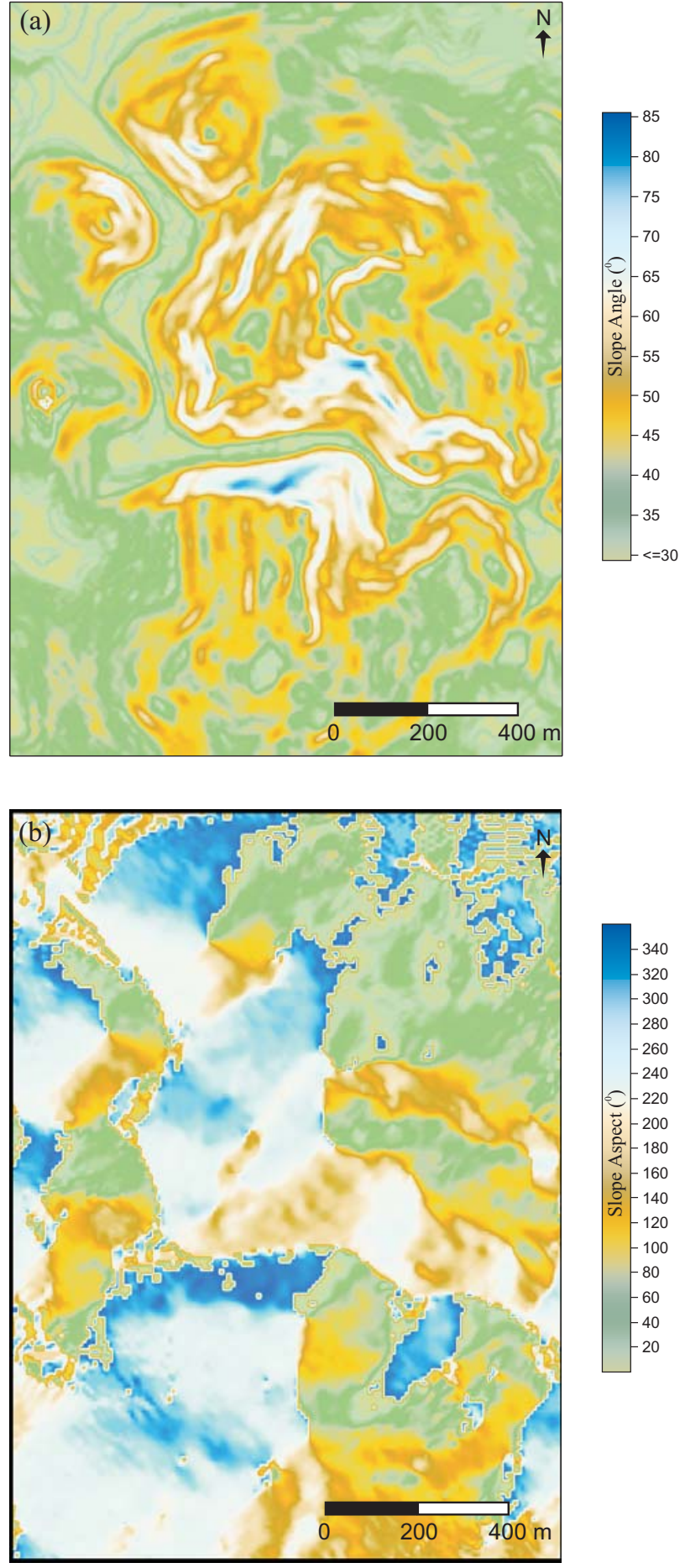

Fig. 3. (a) Slope map of the study area, (b) slope aspect map of the study area.

in different sources (e.g. Ross, 1995; Berkan and Trubatch, 1997; Alvarez Grima, 2000; Negnevitsky, 2002).

When building a rule-based fuzzy model, there are five important steps as: (a) specifying the problem and defining 


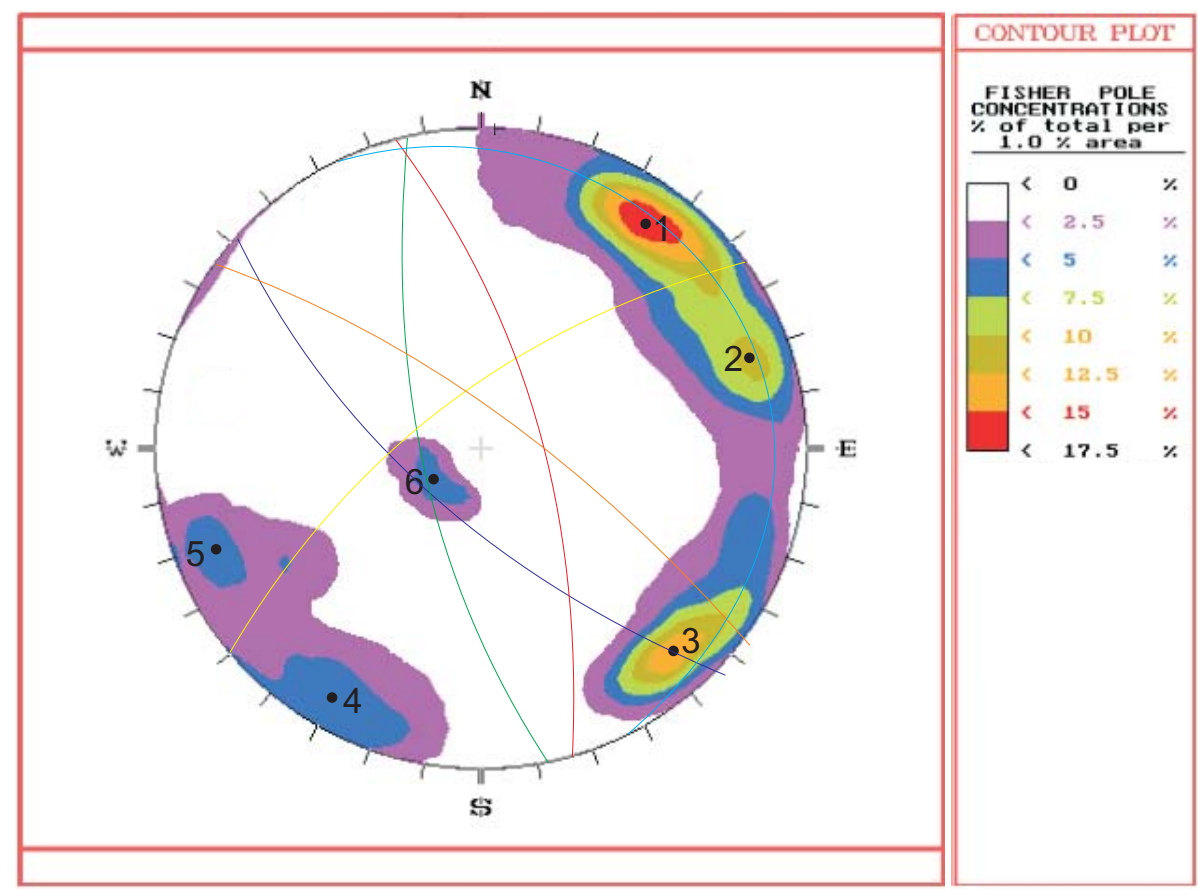

Fig. 4. Presentation of the main discontinuity sets.

$\mathbf{R}_{1}:$ If

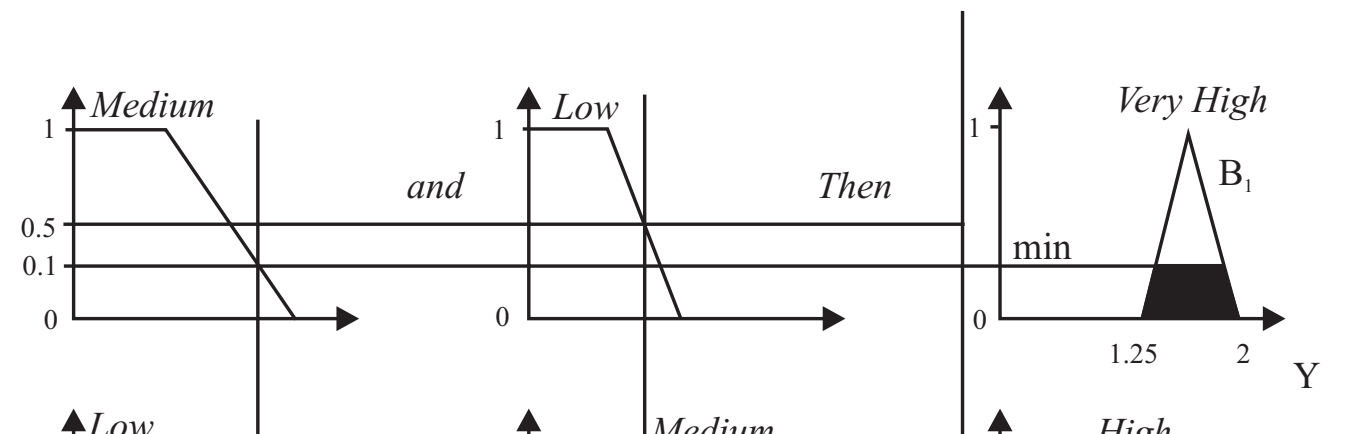

$\mathbf{R}_{2}:$ If

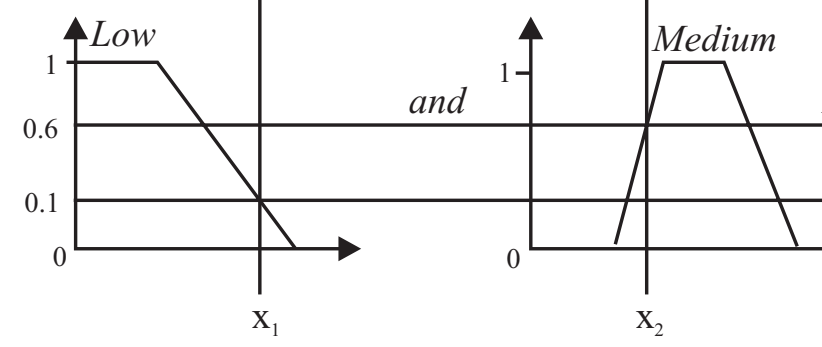

$\boldsymbol{R}_{1}:$ If $x_{1}$ is medium and $x_{2}$ is low Then $Y$ is very high.

$\boldsymbol{R}_{2}:$ If $x_{1}$ is low and $x_{2}$ is medium Then $Y$ is high.

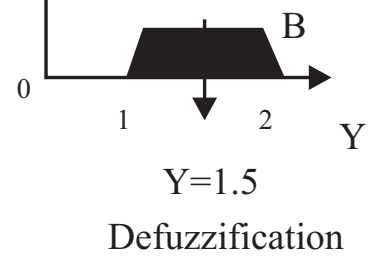

Fig. 5. A schematic representation of Mamdani model (after Alvarez Grima, 2000). 
Table 2. Existing rule-based fuzzy models and their main differences (After Alvarez-Grima, 2000).

\begin{tabular}{lll}
\hline Fuzzy models & Antecedent part of the rule & Consequent part of the rule \\
\hline $\begin{array}{l}\text { Mamdani (linguistic fuzzy } \\
\text { model) } \quad \text { Fuzzy propositions }\end{array}$ & Fuzzy propositions \\
$\begin{array}{l}\text { Mamdani, 1974) } \\
\text { Takagi-Sugeno-Kang fuzzy } \\
\text { model (Takagi and Sugeno, }\end{array}$ & Fuzzy propositions & Mathematical functions \\
$\begin{array}{l}\text { 1985; Sugeno and Tanaka, } \\
\text { 1991) }\end{array}$ & \\
$\begin{array}{l}\text { Tsukamoto fuzzy model } \\
\text { (Tsukamoto, 1979) }\end{array}$ & Fuzzy propositions & Monotonical fuzzy sets \\
Singleton fuzzy model & Fuzzy propositions & Singleton (crisp consequent) \\
\hline
\end{tabular}

linguistic variables; (b) determination of fuzzy sets; (c) elicitation and construction of fuzzy rules; (d) encoding the fuzzy sets, fuzzy rules, and procedures to perform fuzzy inference in to the model; (e) evaluation of the model (Negnevitsky, 2002). These steps were adapted and updated according to the aim of the study to build Mamdani model with respect to the considered input parameters-RSA interaction in the following paragraphs.

\subsection{Step 1}

The first, and probably the most important, step in building the fuzzy model is to specify the problem (Negnevitsky, 2002). To perform this, at the first stage, we selected four input parameters such as altitude difference, number of discontinuities, number of wedges, and number of potential sliding, considered as effective on rockfall initiation in the study area.

The first parameter was the altitude difference. Given the morphology of a rock slope, flat areas, where the altitude difference is zero or very low, were assumed that they could not be source for rockfall regardless of other conditions such as discontinuity orientation, spacing etc. However, areas having higher altitude differences may be RSAs as they have capability of producing rockfall if favorable discontinuity dip and dip direction conditions were reached. In other words, rockfall potential will increase if the altitude difference increases between two neighboring points, i.e., steeper rock slopes will be more suitable for higher potential energy, thus will present greater rockfall hazard potential. Altitude difference was computed with the "Altitude Difference" module of Matterocking. It calculates the maximum height of a slope using maximum difference between two extreme points within the cells of the DEM. In other words, calculated values correspond to a rough estimate of cliff height (Matterocking, 2002). The normalized altitude difference map was given in Fig. 6a, and the linguistic definitions of normalized values were tabulated in Table 3 .

The second parameter was the average number of discontinuities per unit cell. It was calculated by the "Number of Dis- continuities (spacing)" module of Matterocking. It creates a file containing the average number of discontinuities per unit cell using dip, dip direction, and spacing features of discontinuities. To calculate this value for each pixel, discontinuity characteristics were employed (see Table 1). The main idea herein with respect to RSA was that increasing number of discontinuities would increase the capability of producing rock blocks. The normalized number of discontinuities per unit cell map was given in Fig. 6b, and the linguistic definitions of normalized values were tabulated in Table 3. It should be noted that this map was obtained by overlying of 6 different maps showing the characteristics of 6 different discontinuity sets.

The average number of wedges, the third input parameter, was computed by "Number of Wedges" module of Matterocking. This module creates a file containing the average number of wedges per unit cells of the DEM. The idea behind the number of wedge parameter is similar to that of the parameter for the number of discontinuities. To produce a wedge, at least two discontinuity sets are necessary to intersect. Therefore, all possible combinations of 6 discontinuity sets were taken into consideration, and they were overlaid and normalized in $[0,1]$. The final map was obtained and shown in Fig. 6c. Linguistic definitions of this parameter was tabulated in Table 3.

The last input parameter was the average number of potential sliding. "Potential Sliding Zone" module of Matterocking asks for orientation of a discontinuity set. It calculates a file comprising 1 (slide potential) and -1 (no-slide potential) based on the daylight condition in conjunction with slope geometry. For each discontinuity set, dip and dip direction values were fed into the related module. At the end, six files related to the discontinuity sets were overlaid and normalized in $[0,1]$, and a final map was obtained (Fig. 6d). Linguistic definitions of this parameter can be seen in Table 3 . 

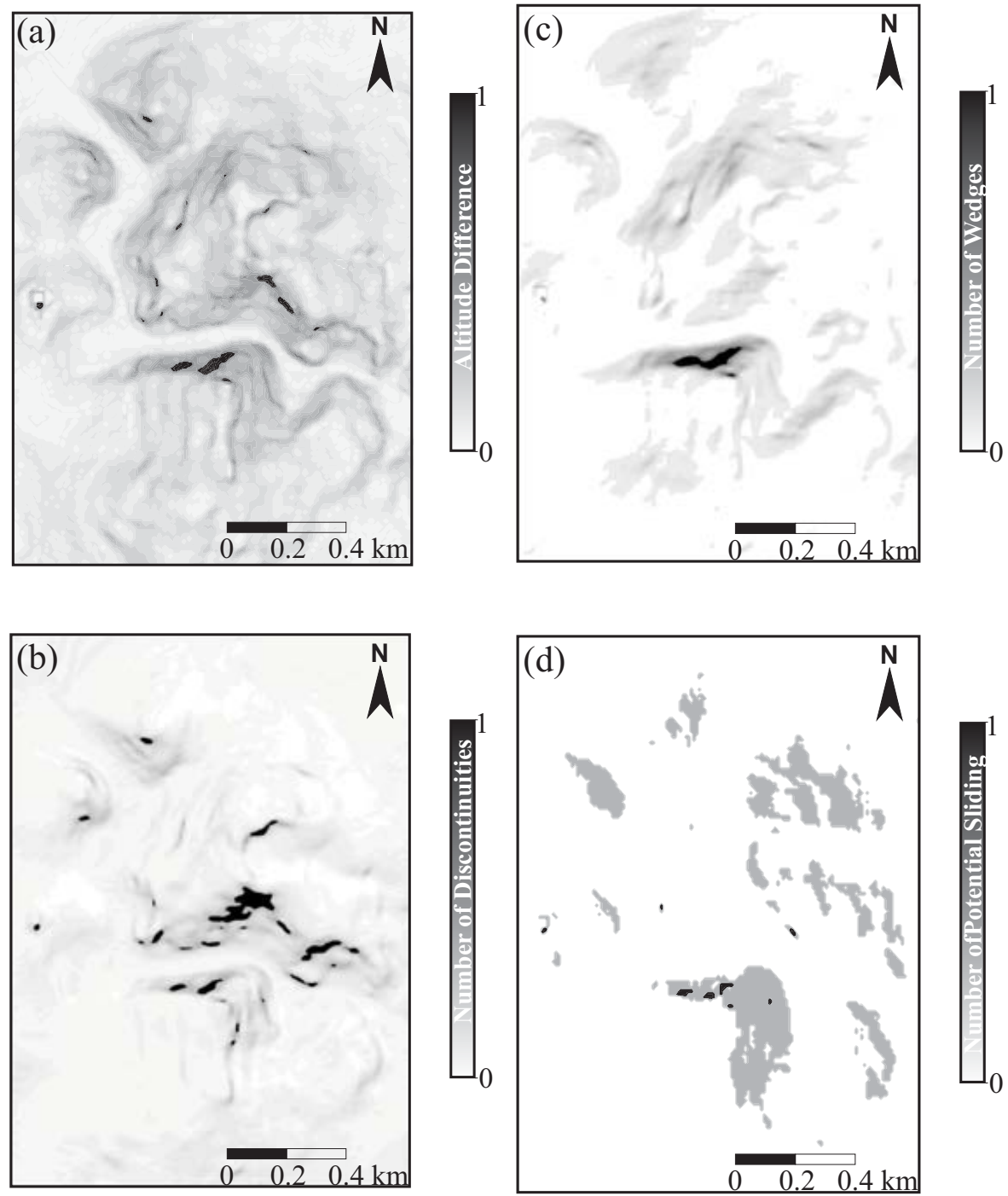

Fig. 6. Input parameter maps: (a) altitude difference, (b) average number of discontinuities (spacing), (c) average number of wedges, (d) average number of potential sliding.

\subsection{Step 2}

In this step, fuzzy sets were defined. Fuzzy sets representing the parameter effect on capability of being RSA were given in Figs. 7a, b, c, d, and e. Triangular and trapezoidal shaped membership functions were selected to define input and output parameters using MATLAB 6.5 (Fuzzy Logic Toolbox) computer program. The boundaries of each linguistic parameter were constituted by means of engineering judgment and expert knowledge, based on the information gathered from the study area.

\section{$5.3 \quad$ Step 3}

As it was explained at the beginning of this section, fuzzy rules define the interaction between the input parameters (antecedent part) and the output (consequent part). Linguistic potential RSA values were assigned in three categories as low $(\mathrm{L})$, medium $(\mathrm{M})$ and high $(\mathrm{H})$ for each parameter and then a total of 81 rules were defined to produce output (i.e. suitability of being source area) considering all possible combinations of sub-groups of altitude difference, number of discontinuities, number of wedges, and number of potential sliding zones. The rules fed into the system were given in Table 4. 
Table 3. Input/output parameters of the fuzzy system and related linguistic definitions.

\begin{tabular}{|c|c|c|c|}
\hline Parameter & Linguistic definition & Shape of function & Normalized range \\
\hline \multirow{3}{*}{ Altitude Difference (AD) } & Low (L) & Triangular & {$[0,0.4]$} \\
\hline & Medium (M) & Triangular & {$[0.3,0.7]$} \\
\hline & $\operatorname{High}(\mathrm{H})$ & Trapezoidal & {$[0.5,0.7,1,1]$} \\
\hline \multirow{3}{*}{ Average Number of Discontinuities (NOD) } & Low (L) & Triangular & {$[0,0.4]$} \\
\hline & Medium (M) & Triangular & {$[0.3,0.7]$} \\
\hline & High $(\mathrm{H})$ & Trapezoidal & {$[0.6,0.8,1,1]$} \\
\hline \multirow{3}{*}{ Average Number of Wedges (NOW) } & Low $(\mathrm{L})$ & Triangular & {$[0,0.4]$} \\
\hline & Medium (M) & Triangular & {$[0.3,0.7]$} \\
\hline & $\operatorname{High}(\mathrm{H})$ & Trapezoidal & {$[0.6,0.8,1,1]$} \\
\hline \multirow{3}{*}{ Average Number of Potential Sliding (PS) } & Low (L) & Triangular & {$[0,0.2]$} \\
\hline & Medium (M) & Triangular & {$[0.15,0.45]$} \\
\hline & High $(\mathrm{H})$ & Trapezoidal & {$[0.4,0.5,1,1]$} \\
\hline \multirow{3}{*}{ Rockfall Source Area (RSA) } & Low $(\mathrm{L})$ & Triangular & {$[0,0.4]$} \\
\hline & Medium (M) & Triangular & {$[0.3,0.7]$} \\
\hline & $\operatorname{High}(\mathrm{H})$ & Triangular & {$[0.6,1]$} \\
\hline
\end{tabular}
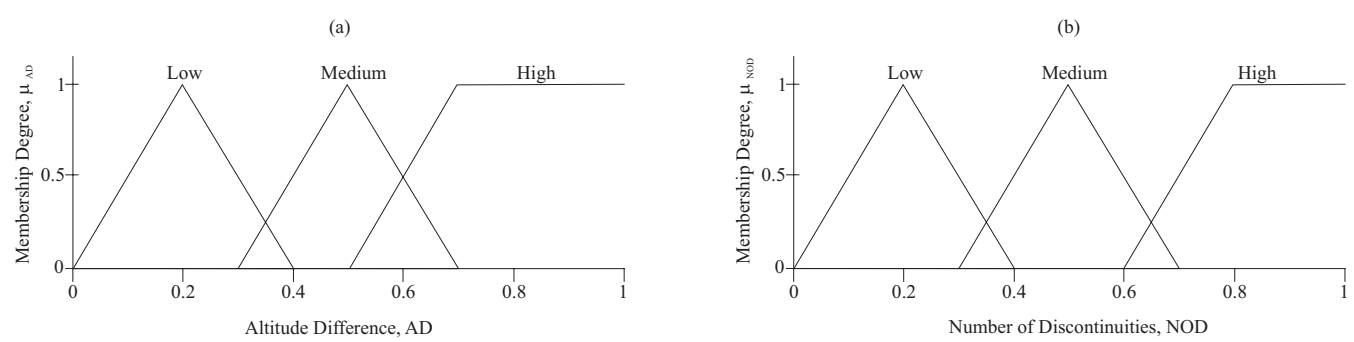

(c)

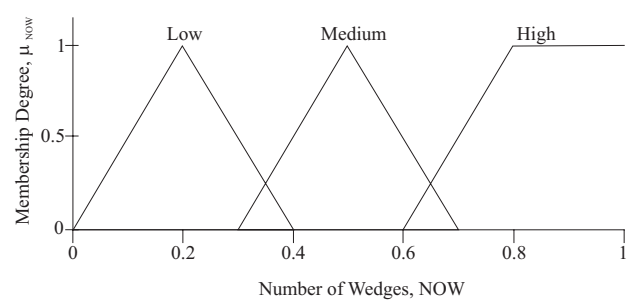

(d)

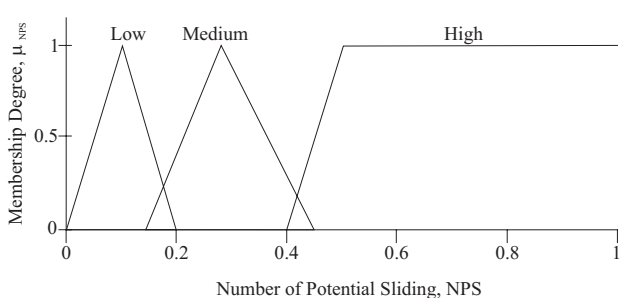

(e)

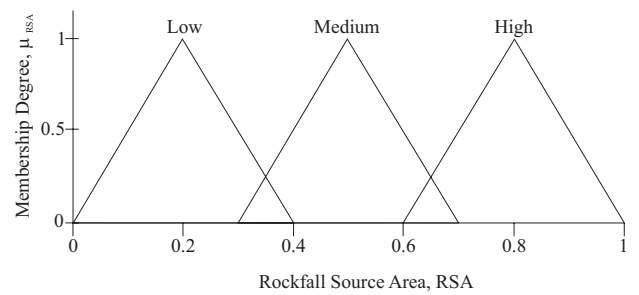

Fig. 7. Fuzzy sets and membership functions for input/output parameters: (a) altitude difference, (b) average number of discontinuities (spacing), (c) average number of wedges, (d) average number of potential sliding, (e) rockfall source area.

\subsection{Step 4}

In this step, fuzzy sets, fuzzy rules, and Mamdani linguistic fuzzy model were combined using Fuzzy Logic Toolbox.
Firstly, inputs were processed to produce output by means of previously defined fuzzy sets and fuzzy rules. Then, fuzzification, rule evaluation, aggregation, and defuzzification processes (see Fig. 5) of Mamdani model were employed. 
Table 4. If-Then rules used in the study.

\begin{tabular}{|c|c|c|c|c|c|c|c|c|c|c|c|}
\hline Rule No & & & & Antec & edent & & & & & Conse & uent Part \\
\hline 1 & If & $\mathrm{AD}=\mathrm{L}$ & and & $\mathrm{NOD}=\mathrm{L}$ & and & $\mathrm{NOW}=\mathrm{L}$ & and & $\mathrm{NPS}=\mathrm{L}$ & Then & RSA is & Low \\
\hline 2 & If & $\mathrm{AD}=\mathrm{L}$ & and & $\mathrm{NOD}=\mathrm{L}$ & and & $\mathrm{NOW}=\mathrm{L}$ & and & $\mathrm{NPS}=\mathrm{M}$ & Then & RSA is & Low \\
\hline 3 & If & $\mathrm{AD}=\mathrm{L}$ & and & $\mathrm{NOD}=\mathrm{L}$ & and & $\mathrm{NOW}=\mathrm{L}$ & and & NPS $=H$ & Then & RSA is & Low \\
\hline 4 & If & $\mathrm{AD}=\mathrm{L}$ & and & $\mathrm{NOD}=\mathrm{L}$ & and & $\mathrm{NOW}=\mathrm{M}$ & and & NPS=L & Then & RSA is & Low \\
\hline 5 & If & $\mathrm{AD}=\mathrm{L}$ & and & $\mathrm{NOD}=\mathrm{L}$ & and & $\mathrm{NOW}=\mathrm{M}$ & and & $\mathrm{NPS}=\mathrm{M}$ & Then & RSA is & Low \\
\hline 6 & If & $\mathrm{AD}=\mathrm{L}$ & and & $\mathrm{NOD}=\mathrm{L}$ & and & $\mathrm{NOW}=\mathrm{M}$ & and & NPS $=\mathrm{H}$ & Then & RSA is & Medium \\
\hline 7 & If & $\mathrm{AD}=\mathrm{L}$ & and & $\mathrm{NOD}=\mathrm{L}$ & and & $\mathrm{NOW}=\mathrm{H}$ & and & NPS=L & Then & RSA is & Low \\
\hline 8 & If & $\mathrm{AD}=\mathrm{L}$ & and & $\mathrm{NOD}=\mathrm{L}$ & and & $\mathrm{NOW}=\mathrm{H}$ & and & $\mathrm{NPS}=\mathrm{M}$ & Then & RSA is & Medium \\
\hline 9 & If & $\mathrm{AD}=\mathrm{L}$ & and & $\mathrm{NOD}=\mathrm{L}$ & and & $\mathrm{NOW}=\mathrm{H}$ & and & NPS $=H$ & Then & RSA is & Medium \\
\hline 10 & If & $\mathrm{AD}=\mathrm{L}$ & and & $\mathrm{NOD}=\mathrm{M}$ & and & $\mathrm{NOW}=\mathrm{L}$ & and & NPS=L & Then & RSA is & Low \\
\hline 11 & If & $\mathrm{AD}=\mathrm{L}$ & and & $\mathrm{NOD}=\mathrm{M}$ & and & $\mathrm{NOW}=\mathrm{L}$ & and & $\mathrm{NPS}=\mathrm{M}$ & Then & RSA is & Low \\
\hline 12 & If & $\mathrm{AD}=\mathrm{L}$ & and & $\mathrm{NOD}=\mathrm{M}$ & and & $\mathrm{NOW}=\mathrm{L}$ & and & NPS $=H$ & Then & RSA is & Medium \\
\hline 13 & If & $\mathrm{AD}=\mathrm{L}$ & and & $\mathrm{NOD}=\mathrm{M}$ & and & $\mathrm{NOW}=\mathrm{M}$ & and & $\mathrm{NPS}=\mathrm{L}$ & Then & RSA is & Low \\
\hline 14 & If & $\mathrm{AD}=\mathrm{L}$ & and & $\mathrm{NOD}=\mathrm{M}$ & and & $\mathrm{NOW}=\mathrm{M}$ & and & NPS & Then & RSA is & Medium \\
\hline 15 & If & $\mathrm{AD}=\mathrm{L}$ & and & $\mathrm{NOD}=\mathrm{M}$ & and & $\mathrm{NOW}=\mathrm{M}$ & and & NPS $=H$ & Then & RSA is & Medium \\
\hline 16 & If & $\mathrm{AD}=\mathrm{L}$ & and & $\mathrm{NOI}$ & and & $\mathrm{N}$ & and & $\mathrm{L}$ & Then & & Medium \\
\hline 17 & If & $\mathrm{AD}=\mathrm{L}$ & and & $\mathrm{NOD}=\mathrm{M}$ & and & & and & & Then & & Medium \\
\hline 18 & If & $\mathrm{AD}=\mathrm{L}$ & and & $\mathrm{NO}$ & and & $\mathrm{NC}$ & and & $\mathrm{N}$ & Then & is & Medium \\
\hline 19 & If & $\mathrm{AD}=\mathrm{L}$ & and & $\mathrm{NOD}=\mathrm{H}$ & and & $\mathrm{NOW}=\mathrm{L}$ & and & NPS=L & Then & RSA is & Low \\
\hline 20 & If & $\mathrm{AD}=\mathrm{L}$ & and & NOI & and & NO & and & $\mathrm{NPS}=\mathrm{M}$ & Then & & Medium \\
\hline 21 & If & $\mathrm{AD}=\mathrm{L}$ & and & $\mathrm{NOD}=\mathrm{H}$ & and & $\mathrm{NOW}=\mathrm{L}$ & and & NPs & Then & is & Medium \\
\hline 22 & If & $\mathrm{AD}=\mathrm{L}$ & and & $\mathrm{NOD}=\mathrm{H}$ & and & $\mathrm{NC}$ & and & $\mathrm{L}$ & Then & is & Medium \\
\hline 23 & If & $\mathrm{AD}=\mathrm{L}$ & and & $\mathrm{NOD}=\mathrm{H}$ & and & NO & and & NPS & Then & is & Medium \\
\hline 24 & If & $\mathrm{AD}=\mathrm{L}$ & and & $\mathrm{NOD}=\mathrm{H}$ & and & $\mathrm{NOW}=\mathrm{M}$ & and & NPS $=H$ & Then & RSA is & Medium \\
\hline 25 & If & $\mathrm{AD}=\mathrm{L}$ & and & $\mathrm{NO}$ & and & & & & Then & & Medium \\
\hline 26 & If & $\mathrm{AD}=\mathrm{L}$ & and & $\mathrm{NOD}=\mathrm{H}$ & and & & and & $\mathrm{M}$ & Then & $\mathrm{SA}$ is & Medium \\
\hline 27 & If & $\mathrm{AD}=\mathrm{L}$ & and & NOI & and & $\mathrm{NO}$ & and & & Then & & $\mathrm{High}$ \\
\hline 28 & If & $\mathrm{AD}=\mathrm{M}$ & and & $\mathrm{NOD}=\mathrm{L}$ & and & $\mathrm{NOW}=\mathrm{L}$ & and & NPS $=\mathrm{L}$ & Then & RSA is & Low \\
\hline 29 & If & $\mathrm{AD}=\mathrm{M}$ & and & $\mathrm{NOD}=\mathrm{L}$ & and & $\mathrm{NOW}=\mathrm{L}$ & and & $\mathrm{NF}$ & Then & is & Low \\
\hline 30 & If & $\mathrm{AD}=$ & and & $\mathrm{NOD}=\mathrm{L}$ & and & NO & and & NP & Then & RSA is & Medium \\
\hline 31 & If & $\mathrm{AD}=\mathrm{M}$ & and & $\mathrm{NOD}=\mathrm{L}$ & and & NO & and & NPs & Then & RSA is & Low \\
\hline 32 & If & $\mathrm{AD}=\mathrm{M}$ & and & $\mathrm{NOD}=\mathrm{L}$ & and & $\mathrm{NOW}=\mathrm{M}$ & and & $\mathrm{NPS}=\mathrm{M}$ & Then & RSA is & Medium \\
\hline 33 & If & $\mathrm{AD}=\mathrm{M}$ & and & $\mathrm{NOD}=\mathrm{L}$ & and & $\mathrm{NOW}=\mathrm{M}$ & and & NPS $=H$ & Then & RSA is & Medium \\
\hline 34 & If & $\mathrm{AD}=\mathrm{M}$ & and & $\mathrm{NOD}=\mathrm{L}$ & and & & and & $=\mathrm{L}$ & Then & is & Medium \\
\hline 35 & If & $\mathrm{AD}=$ & and & NO & and & $\mathrm{N}$ & and & NPs & Then & RSA is & Medium \\
\hline 36 & If & $\mathrm{AD}=\mathrm{M}$ & and & $\mathrm{NOD}=\mathrm{L}$ & and & $\mathrm{NO}$ & and & NPS $=H$ & Then & RSA is & Medium \\
\hline 37 & If & $\mathrm{AD}=\mathrm{M}$ & and & $\mathrm{NOD}=\mathrm{M}$ & and & $\mathrm{NOW}=\mathrm{L}$ & and & NPS=L & Then & RSA is & Low \\
\hline 38 & If & $\mathrm{AD}=\mathrm{M}$ & and & $\mathrm{NOD}=\mathrm{M}$ & and & $\mathrm{NOW}=\mathrm{L}$ & and & $\mathrm{NPS}=\mathrm{M}$ & Then & RSA is & Medium \\
\hline 39 & If & $\mathrm{AD}=\mathrm{M}$ & and & $\mathrm{NOD}=\mathrm{M}$ & and & & and & $=\mathrm{H}$ & Then & is & Medium \\
\hline 40 & If & $\mathrm{AD}=$ & and & $\mathrm{NOD}=\mathrm{M}$ & and & $\mathrm{NO}$ & an & $\mathrm{NP}$ & Then & RSA is & Medium \\
\hline 41 & If & $\mathrm{AD}=\mathrm{M}$ & and & $\mathrm{NOD}=\mathrm{M}$ & and & $\mathrm{NOW}=\mathrm{M}$ & and & $\mathrm{NPS}=\mathrm{M}$ & Then & RSA is & Medium \\
\hline 42 & If & $\mathrm{AD}=\mathrm{M}$ & and & $\mathrm{NOD}=\mathrm{M}$ & and & $\mathrm{NOW}=\mathrm{M}$ & and & NPS $=H$ & Then & RSA is & Medium \\
\hline 43 & If & $\mathrm{AD}=\mathrm{M}$ & and & $\mathrm{NOD}=\mathrm{M}$ & and & & and & NPS=L & Then & RSA is & Medium \\
\hline 44 & If & $\mathrm{AD}=\mathrm{M}$ & and & $\mathrm{NOD}=\mathrm{M}$ & an & & an & $\mathrm{NPS}=\mathrm{M}$ & Then & RSA is & Medium \\
\hline 45 & If & $\mathrm{AD}=$ & and & $\mathrm{NOD}=\mathrm{M}$ & and & $\mathrm{NO}$ & an & NP & Then & RSA is & $\mathrm{High}$ \\
\hline 46 & If & $\mathrm{AD}=\mathrm{M}$ & and & $\mathrm{NOD}=\mathrm{H}$ & and & $\mathrm{NOW}=\mathrm{L}$ & and & NPS=L & Then & RSA is & Medium \\
\hline 47 & If & $\mathrm{AD}=\mathrm{M}$ & and & $\mathrm{NOD}=\mathrm{H}$ & and & $\mathrm{NOW}=\mathrm{L}$ & and & $\mathrm{NPS}=\mathrm{M}$ & Then & RSA is & Medium \\
\hline 48 & If & $\mathrm{AD}=\mathrm{M}$ & and & $\mathrm{NOD}=\mathrm{H}$ & and & $\mathrm{NOW}=\mathrm{L}$ & and & NPS $=H$ & Then & RSA is & Medium \\
\hline 49 & If & $\mathrm{AD}=\mathrm{M}$ & and & $\mathrm{NOD}=\mathrm{H}$ & and & & and & NPS=L & Then & RSA is & Medium \\
\hline 50 & If & $\mathrm{AD}=\mathrm{M}$ & and & NOD & and & NO & and & $\mathrm{NPS}=\mathrm{M}$ & Then & RSA is & Medium \\
\hline 51 & If & $\mathrm{AD}=\mathrm{M}$ & and & $\mathrm{NOD}=\mathrm{H}$ & and & $\mathrm{NOW}=\mathrm{M}$ & and & $\mathrm{NPS}=\mathrm{H}$ & Then & RSA is & High \\
\hline 52 & If & $\mathrm{AD}=\mathrm{M}$ & and & $\mathrm{NOD}=\mathrm{H}$ & and & $\mathrm{NOW}=\mathrm{H}$ & and & $\mathrm{NPS}=\mathrm{L}$ & Then & RSA is & Medium \\
\hline 53 & If & $\mathrm{AD}=\mathrm{M}$ & and & $\mathrm{NOD}=\mathrm{H}$ & and & $\mathrm{NOW}=\mathrm{H}$ & and & $\mathrm{NPS}=\mathrm{M}$ & Then & RSA is & High \\
\hline
\end{tabular}


Table 4. Continued.

\begin{tabular}{|c|c|c|c|c|c|c|c|c|c|c|c|}
\hline Rule No & & & & Ante & dent $\mathrm{F}$ & & & & & Consec & dent Part \\
\hline 54 & If & $\mathrm{AD}=\mathrm{M}$ & and & $\mathrm{NOD}=\mathrm{H}$ & and & $\mathrm{NOW}=\mathrm{H}$ & and & $\mathrm{NPS}=\mathrm{H}$ & Then & $\mathrm{RSA}$ is & High \\
\hline 55 & If & $\mathrm{AD}=\mathrm{H}$ & and & $\mathrm{NOD}=\mathrm{L}$ & and & $\mathrm{NOW}=\mathrm{L}$ & and & $\mathrm{NPS}=\mathrm{L}$ & Then & $\mathrm{RSA}$ is & Low \\
\hline 56 & If & $\mathrm{AD}=\mathrm{H}$ & and & $\mathrm{NOD}=\mathrm{L}$ & and & $\mathrm{NOW}=\mathrm{L}$ & and & $\mathrm{NPS}=\mathrm{M}$ & Then & RSA is & Medium \\
\hline 57 & If & $\mathrm{AD}=\mathrm{H}$ & and & $\mathrm{NOD}=\mathrm{L}$ & and & $\mathrm{NOW}=\mathrm{L}$ & and & $\mathrm{NPS}=\mathrm{H}$ & Then & RSA is & Medium \\
\hline 58 & If & $\mathrm{AD}=\mathrm{H}$ & and & $\mathrm{NOD}=\mathrm{L}$ & and & $\mathrm{NOW}=\mathrm{M}$ & and & $\mathrm{NPS}=\mathrm{L}$ & Then & RSA is & Medium \\
\hline 59 & If & $\mathrm{AD}=\mathrm{H}$ & and & $\mathrm{NOD}=\mathrm{L}$ & and & $\mathrm{NOW}=\mathrm{M}$ & and & $\mathrm{NPS}=\mathrm{M}$ & Then & RSA is & Medium \\
\hline 60 & If & $\mathrm{AD}=\mathrm{H}$ & and & $\mathrm{NOD}=\mathrm{L}$ & and & $\mathrm{NOW}=\mathrm{M}$ & and & $\mathrm{NPS}=\mathrm{H}$ & Then & $\mathrm{RSA}$ is & Medium \\
\hline 61 & If & $\mathrm{AD}=\mathrm{H}$ & and & $\mathrm{NOD}=\mathrm{L}$ & and & $\mathrm{NOW}=\mathrm{H}$ & and & $\mathrm{NPS}=\mathrm{L}$ & Then & RSA is & Medium \\
\hline 62 & If & $\mathrm{AD}=\mathrm{H}$ & and & $\mathrm{NOD}=\mathrm{L}$ & and & $\mathrm{NOW}=\mathrm{H}$ & and & $\mathrm{NPS}=\mathrm{M}$ & Then & RSA is & Medium \\
\hline 63 & If & $\mathrm{AD}=\mathrm{H}$ & and & $\mathrm{NOD}=\mathrm{L}$ & and & $\mathrm{NOW}=\mathrm{H}$ & and & $\mathrm{NPS}=\mathrm{H}$ & Then & $\mathrm{RSA}$ is & High \\
\hline 64 & If & $\mathrm{AD}=\mathrm{H}$ & and & $\mathrm{NOD}=\mathrm{M}$ & and & $\mathrm{NOW}=\mathrm{L}$ & and & $\mathrm{NPS}=\mathrm{L}$ & Then & $\mathrm{RSA}$ is & Medium \\
\hline 65 & If & $\mathrm{AD}=\mathrm{H}$ & and & $\mathrm{NOD}=\mathrm{M}$ & and & $\mathrm{NOW}=\mathrm{L}$ & and & $\mathrm{NPS}=\mathrm{M}$ & Then & $\mathrm{RSA}$ is & Medium \\
\hline 66 & If & $\mathrm{AD}=\mathrm{H}$ & and & $\mathrm{NOD}=\mathrm{M}$ & and & $\mathrm{NOW}=\mathrm{L}$ & and & $\mathrm{NPS}=\mathrm{H}$ & Then & RSA is & Medium \\
\hline 67 & If & $\mathrm{AD}=\mathrm{H}$ & and & $\mathrm{NOD}=\mathrm{M}$ & and & $\mathrm{NOW}=\mathrm{M}$ & and & $\mathrm{NPS}=\mathrm{L}$ & Then & RSA is & Medium \\
\hline 68 & If & $\mathrm{AD}=\mathrm{H}$ & and & $\mathrm{NOD}=\mathrm{M}$ & and & $\mathrm{NOW}=\mathrm{M}$ & and & $\mathrm{NPS}=\mathrm{M}$ & Then & $\mathrm{RSA}$ is & Medium \\
\hline 69 & If & $\mathrm{AD}=\mathrm{H}$ & and & $\mathrm{NOD}=\mathrm{M}$ & and & $\mathrm{NOW}=\mathrm{M}$ & and & $\mathrm{NPS}=\mathrm{H}$ & Then & $\mathrm{RSA}$ is & High \\
\hline 70 & If & $\mathrm{AD}=\mathrm{H}$ & and & $\mathrm{NOD}=\mathrm{M}$ & and & $\mathrm{NOW}=\mathrm{H}$ & and & $\mathrm{NPS}=\mathrm{L}$ & Then & $\mathrm{RSA}$ is & Medium \\
\hline 71 & If & & and & $\mathrm{NOD}=\mathrm{M}$ & and & $\mathrm{NOW}=\mathrm{H}$ & and & $\mathrm{NPS}=\mathrm{M}$ & Then & $\mathrm{RSA}$ is & High \\
\hline 72 & If & $\mathrm{AD}=\mathrm{H}$ & and & $\mathrm{NOD}=\mathrm{M}$ & and & $\mathrm{NOW}=\mathrm{H}$ & and & $\mathrm{NPS}=\mathrm{H}$ & Then & $\mathrm{RSA}$ is & High \\
\hline 73 & If & $\mathrm{AD}=\mathrm{H}$ & and & $\mathrm{NOD}=\mathrm{H}$ & and & $\mathrm{NOW}=\mathrm{L}$ & and & $\mathrm{NPS}=\mathrm{L}$ & Then & $\mathrm{RS}$ & Medium \\
\hline 74 & If & $\mathrm{AD}=\mathrm{H}$ & and & $\mathrm{NOD}=\mathrm{H}$ & and & $\mathrm{NOW}=\mathrm{L}$ & and & $\mathrm{NPS}=\mathrm{M}$ & Then & RSA is & Medium \\
\hline 75 & If & $\mathrm{AD}=\mathrm{H}$ & and & $\mathrm{NOD}=\mathrm{H}$ & and & $\mathrm{NOW}=\mathrm{L}$ & and & $\mathrm{NPS}=\mathrm{H}$ & Then & RSA is & High \\
\hline 76 & If & $\mathrm{AD}=\mathrm{H}$ & and & $\mathrm{NOD}=\mathrm{H}$ & and & $\mathrm{NOW}=\mathrm{M}$ & and & $\mathrm{NPS}=\mathrm{L}$ & Then & $\mathrm{RSA}$ is & Medium \\
\hline 77 & If & $\mathrm{AD}=\mathrm{H}$ & and & $\mathrm{NOD}=\mathrm{H}$ & and & $\mathrm{NOW}=\mathrm{M}$ & and & $\mathrm{NPS}=\mathrm{M}$ & Then & $\mathrm{RSA}$ is & High \\
\hline 78 & If & $\mathrm{AD}=\mathrm{H}$ & and & $\mathrm{NOD}=\mathrm{H}$ & and & $\mathrm{NOW}=\mathrm{M}$ & and & $\mathrm{NPS}=\mathrm{H}$ & Then & RSA is & High \\
\hline 79 & If & $\mathrm{AD}=\mathrm{H}$ & and & $\mathrm{NOD}=\mathrm{H}$ & and & $\mathrm{NOW}=\mathrm{H}$ & and & $\mathrm{NPS}=\mathrm{L}$ & Then & RSA is & High \\
\hline 80 & If & $\mathrm{AD}=\mathrm{H}$ & and & $\mathrm{NOD}=\mathrm{H}$ & and & $\mathrm{NOW}=\mathrm{H}$ & and & $\mathrm{NPS}=\mathrm{M}$ & Then & $\mathrm{RSA}$ is & High \\
\hline 81 & If & $\mathrm{AD}=\mathrm{H}$ & and & $\mathrm{NOD}=\mathrm{H}$ & and & $\mathrm{NOW}=\mathrm{H}$ & and & $\mathrm{NPS}=\mathrm{H}$ & Then & $\mathrm{RSA}$ is & High \\
\hline
\end{tabular}

During the defuzzification process, centroid method, which is generally used in that kind of applications because of its simplicity and producing consistent results, was chosen.

\subsection{Step 5}

In this step, outputs of the rule-based fuzzy system analyses processed to produce RSA were used. To perform this, outputs of the system were assigned to produce RSA maps based on fuzzy sets defined in the Step 2 and original input values replaced with linguistic definitions. This process was repeated for all combinations of the input parameters and their subgroups, and final RSA map (Fig. 8) was obtained.

\subsection{Step 6}

At the last step, after obtaining the RSAs ranging between low and high (actually in $[0,1]$ ), in order to evaluate rockfall potential, another computer program, Conefall (2003), was used. It is designed to estimate roughly the potential rockfall prone areas based on the given RSAs. The theory behind the program was based on the logic proposed by Evans and Hungr (1993), and it was used in different rockfall haz- ard assessments and applications effectively (e.g. Jaboyedoff and Labiouse, 2003). In order to evaluate the areas to be affected by rockfall hazard, firstly, RSAs should be defined. Using the ASCII *.grd file of RSAs obtained in the previous step (see Fig. 8), it was entered as inputs to the program with DEM ASCII *.grd file of the study area. In the program -1 and +1 values were defined for "not source area" and "source area", respectively. The areas having low RSA values were not taken into consideration as they also contain zero RSAs, not having contribution to rockfall initiation. Therefore, two different RSAs, assigned as medium and high, were entered to the program separately to produce a rockfall potential map. Taking into account the cone angle $33^{\circ}$ in the program (proposed by M. Jaboyedoff in private communication, as obtained from his experience in different applications) and RSAs (medium and high) determined in the previous step, the rockfall potential map showing medium and high rockfall potential was obtained by combining them with overlaying process (Fig. 9). 


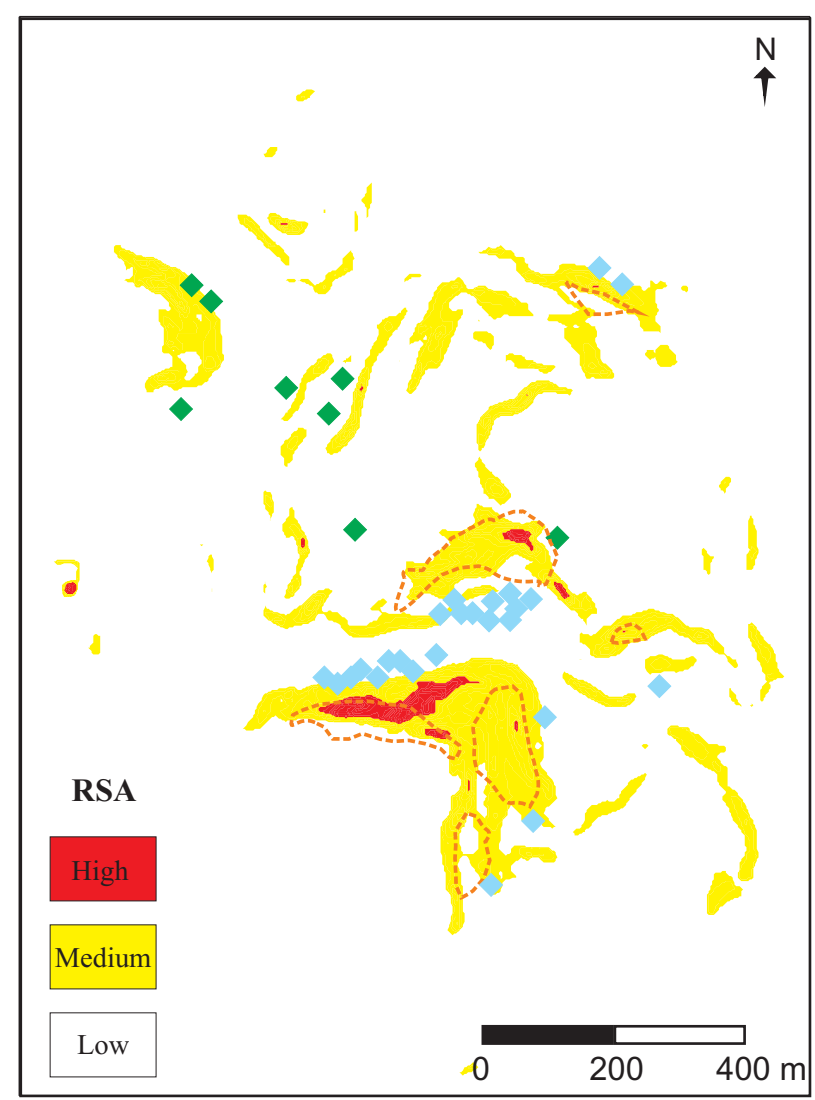

Possible RSAs

Observed rockfalls of obvious origin

Observed rockfalls of uncertain origin

Fig. 8. RSA map of the study area.

\section{Results and conclusions}

Following results and conclusions can be drawn from this study:

(1) The main objective in starting the present study was to determine the RSAs around the Ankara Castle area and its vicinity as there had been several rockfall incidences, causing rock blocks to hit many houses, fall on the roads, and give rise to damage to other facilities. In this study, a rule-based fuzzy system was used to evaluate the RSAs in an urban settlement, where many houses had been unconsciously built very close to the historical Ankara Castle and in old andesite quarries. A potential rockfall hazard map was also produced to satisfy the lack of rockfall assessment in the study area. Despite the fact that rockfall hazard potential was emphasized in almost all previous studies carried out in the same area, there were neither qualitative and/or quantitative evaluation considering rockfall event, nor a rockfall in-
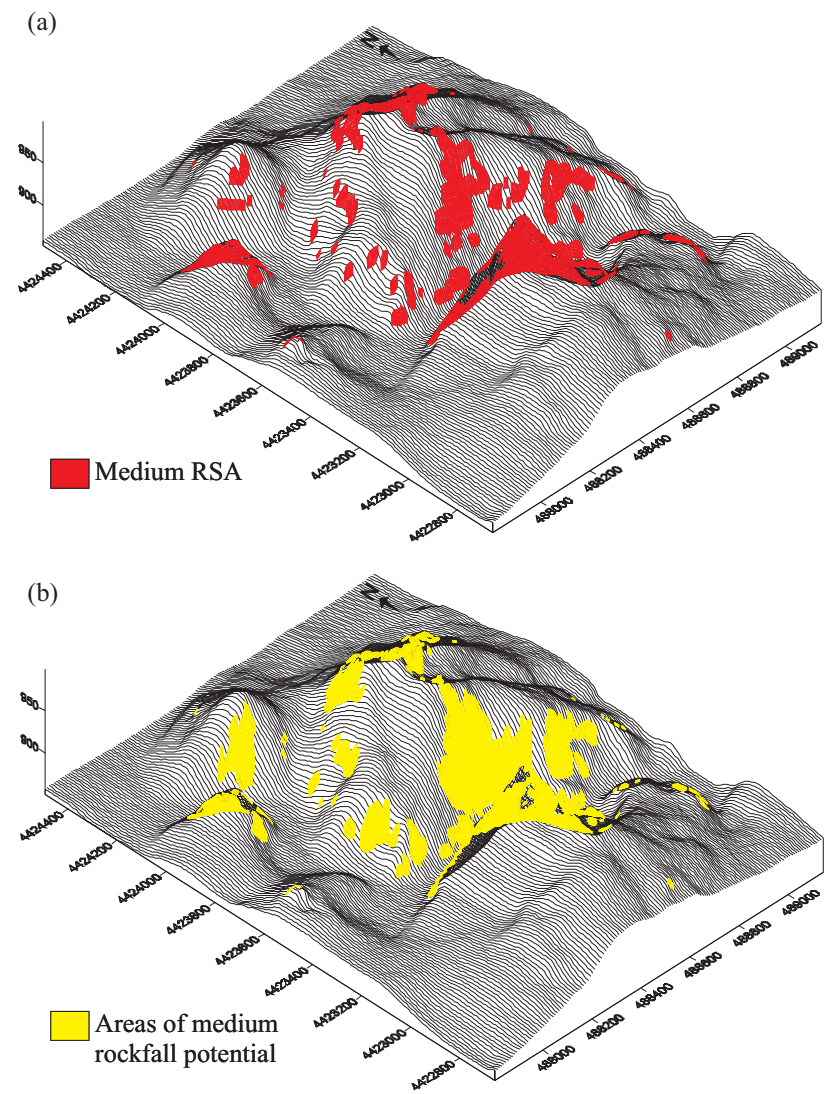

Fig. 9. Potential rockfall hazard map of the study area.

ventory and/or database, which could be considered as one of the most important stages of any natural hazard assessment.

(2) Four different parameters such as altitude difference, number of discontinuities, number of wedges, and number of potential sliding were selected as the inputs of the rule-based fuzzy system based on the data availability and engineering judgment. These parameters were processed in the fuzzy system to produce output (i.e. degree of being RSA). Based on the so-produced RSA maps, representing high and medium degrees of RSA, 1.7\% of the study area was found to have "high RSA", while $5.8 \%$ of the study area was assigned as "medium RSA". The selected parameters and the methodology employed in this study were considered as satisfactory since most of the potential RSAs mapped during the field studies coincided with these zones. However, there are also other zones of high or medium RSAs. These zones were generally located on the settlement areas. Although the rockfall events were observed in the screes of these zones during the field studies, it was not possible to map the RSAs of these zones due to the dense settlement. 
This situation also concluded that there could be more RSAs than expected.

(3) Potential rockfall hazard map was prepared to show high and medium potential rockfall hazard zones. According to this map based upon the high and medium RSAs, $3.6 \%$ of the study area showed "high rockfall potential", while areal distribution of "medium rockfall potential" was found as $7.9 \%$. If the ratios of being RSA and capability of producing rockfall hazard were taken into consideration, it may be concluded that the "high RSAs" have much greater capability of producing rockfall potential than those of the "medium RSAs" with respect to areal distributions. In addition, according to this map, a considerable amount of area in the urban settlement district and roads seemed to be under rockfall threat.

(4) Although mapping of RSA and rockfall potential seem to be easy to map during field work by direct mapping, it is not always possible to produce consistent maps due to the complex nature of rockfall phenomenon. In fact, modeling the rockfall potential and/or producing rockfall scenarios using constant geomechanical parameters and topographical irregularities may cause incorrect results particularly for the slopes boasting complex features. For example, numerical and/or analytical approaches, based upon generally geomechanical and topographical features of the slopes, may be affected by the parametric diversity of the considered slopes and materials, so that they may not represent actual conditions and may be insufficient. Furthermore, it is not easy to evaluate which parameter played the most important role on the rockfall occurrence. Under these conditions, soft computing techniques such as fuzzy logic, considering all parametric relations and their effects as a whole for the defined problem, can be used to evaluate the rather complex nature of the rockfall event, at least for the initial stage of the evaluation processes. It would be recommended to perform further detailed numerical and analytical treatment after determining potentially hazardous areas.

(5) Resulting maps may be useful for the decision makers and municipality planners, and provide information about the rockfall phenomenon for the area in concern. It should be noted that the rockfall hazard maps produced in this study do not intend to be integrated as a part of any settlement planning project in the study area. However, such a work would yield useful information on potentially safe and unsafe zones if carried out especially prior to any site selection decision in an area prone to rockfall hazard.

Acknowledgements. The authors would like to thank M. Jaboyedoff for his suggestions and comments in using the program
CONEFALL and producing rockfall source map. The authors would also like to thank T. Glade (Editor) and T. Topal for their evaluation and valuable comments and encouragement, which increased the quality of the paper.

Edited by: T. Glade

Reviewed by: M. Jaboyedoff and T. Topal

\section{References}

Abdolmasov, B. and Obradovic, I.: Evaluation of geological parameters for landslide hazard mapping, Proc. Int. Symp. Eng. Geol.\&Env., 23-27 June 1997, Athens, Greece, edited by: Marinos, P. G., Koukis, G. C., Tsiambaos, G. C., and Stournaras, G. C., Balkema, 471-476, 1997.

Agliardi, F. and Crosta, G. B.: High resolution three-dimensional numerical modelling of rockfalls, International Journal of Rock Mechanics\&Mining Sciences, 40, 455-471, 2003.

Aleotti, P. and Chowdhury, R.: Landslide hazard assessment: summary review and new perspectives, Bull. Eng. Geol. Environ., 58, 21-44, 1999.

Alvarez Grima, M.: Neuro-fuzzy Modeling in Engineering Geology, Balkema, Rotterdam, 2000.

Ayala-Carcedo, F. J., Cubillo-Nielsen, S., Alvarez, A., Dominguez, M. J., Lain, L., Lain, R., and Ortiz, G.: large scale rockfall reach susceptibility maps in La Cabrera Sierra (Madrid) performed with GIS and dynamic analysis at 1:5000, Nat. Hazards, 30, 325$340,2003$.

Baillifard, F., Jaboyedoff, M., and Sartori, M.: Rockfall hazard mapping along a mountainous road in Switzerland using a GISbased parameter rating approach, Nat. Hazards Earth Syst. Sci., 3, 431-438, 2003, http://www.nat-hazards-earth-syst-sci.net/3/431/2003/.

Berkan, R. C. and Trubatch, S. L.: Fuzzy Systems Design Principles, IEEE Neural Networks Council, New York, 1997.

Chi, K., Park, N. W., and Chung, C. J.: Fuzzy logic integration for landslide hazard mapping using spatial data from Boeun, Korea, Symposium on Geospatial Theory, Processing and Applications, Ottawa, 283-288, 2002.

Coggan, J. S., Stead, D., and Eyre, J. M.: Evaluation of techniques for quarry slope stability assessment, Trans. Instit. Min. Metall., 107, B139-B147, 1998.

Conefall (1.0): User's Guide. Open report - Soft 01,Quanterra, http: //www.quanterra.org, 15 p., 2003

Crosta, G. B. and Agliardi, F.: A methodology for physically based rockfall hazard assessment, Nat. Hazards Earth Syst. Sci., 3, 407-422, 2003 http://www.nat-hazards-earth-syst-sci.net/3/407/2003/.

Crosta, G. B., Imposimato, S., and Roddeman, D. G.: Numerical modelling of large landslides stability and runout, Nat. Hazards Earth Syst. Sci., 3, 523-538, 2003, http://www.nat-hazards-earth-syst-sci.net/3/523/2003/.

Crosta, G. B. and Agliardi, F.: Parametric evaluation of 3D dispersion of rockfall trajectories, Nat. Hazards Earth Syst. Sci., 4 , 583-598, 2004, http://www.nat-hazards-earth-syst-sci.net/4/583/2004/.

Crosta, G. B., Frattini, P., Carrara, A., Agliardi, F., and Campedel, P.: An integrated statistical and physically-based approach for 
rockfall susceptibility assessment, Geophys. Res. Abstr., 8, 08255, 2006.

Diedrics, M. S. and Hoek, E.: DIPS, a computer program for stereographic net (Version 2.2, Advanced Version), Rock Engineering Group, Department of Civil Engineering Group, University of Toronto, Toronto, Canada, 1989.

Dorren, L. K. A.: Mountain geoecosystems: GIS modelling of rockfall and protection forest structure, Thesis Universiteit van Amsterdam, ISBN: 90-9016094-9, 162 p., 2002.

Dorren, L. K. A., Maier, B., Putters, U. S., and Seijmonsbergen, A. C.: Combining field and modelling techniques to assess rockfall dynamics on a protection forest hillslope in the European Alps, Geomorphology, 57, 151-167, 2004.

Duarte, R. M. and Marquinez, J.: The influence of environmental and lithologic factors on rockfall at a regional scale: an evaluation using GIS, Geomorphology, 43, 117-136, 2002.

Dussauge-Peisser, C., Helmstetter, A., Grasso, J. R., Hantz, D., Desvarreux, P., Jeannin, M., and Giraud A.: Probabilistic approach to rock fall hazard assessment: potential of historical data analysis, Nat. Hazards Earth Syst. Sci., 2, 15-26, 2002,

http://www.nat-hazards-earth-syst-sci.net/2/15/2002/.

Ercanoglu, M.: Investigation of possible modes of instability and preparation of instability map of andesites in Altindag (Ankara) settlement region, MSc Thesis, Hacettepe University (in Turkish, unpublished), 1997.

Ercanoglu, M. and Gokceoglu, C.: Assessment of landslide susceptibility for a landslide-prone area (North of Yenice, NW Turkey) by fuzzy approach, Environ. Geol., 41, 720-730, 2002.

Ercanoglu, M. and Aksoy, H.: Potential instability map for rock slopes at Ankara Castle and vicinity, Yerbilimleri (in Turkish), 29, 97-114, 2004.

Ercanoglu, M. and Gokceoglu, C.: Use of fuzzy relations to produce landslide susceptibility map of a landslide prone area (West Black Sea Region, Turkey), Eng. Geol., 75, 229-250, 2004.

Erentoz, C.: 1/15000 scaled Turkey Geological Map, Ankara Region, MTA Press, (in Turkish), 1975.

Erol, O.: Tectonic development of Ankara region. Bulletin of TJK, (in Turkish), 7, 57-85, 1961.

Evans, S. and Hungr, O.: The assessment of rockfall hazard at the base of talus slopes, Canadian. Geotechnical Journal, 30, 620636, 1993.

Glade, T. and Crozier, M. J.: A review of scale dependency in landslide hazard and risk analysis, in: Landslide Hazard and Risk, edited by: Glade, T., Anderson, M., and Crozier, M. J., Part 3, John Wiley\&Sons, 75-138, 2005.

Gokceoglu, C., Sonmez, H., and Ercanoglu, M.: Discontinuity controlled probabilistic risk maps of the Altindag (settlement) region in Turkey, Engineering Geology, 55, 277-296, 2000.

Gorsevski, P. V., Gessler, P. E., and Jankowski, P.: Integrating a fuzzy k-means classification and a Bayesian approach for spatial prediction of landslide hazard, J. Geog. Syst., 5, 223-251, 2003.
Guzzetti, F., Reichenbach, P., and Wieczorek, G. F.: Rockfall hazard and risk assessment in the Yosemite Valley, California, USA, Nat. Hazards Earth Syst. Sci., 3, 491-503, 2003, http://www.nat-hazards-earth-syst-sci.net/3/491/2003/.

Hantz, D., Vengeon, J. M., and Dussauge-Peisser, C.: An historical, geomechanical and probabilistic approach to rock-fall hazard assessment, Nat. Hazards Earth Syst. Sci., 3, 693-701, 2003, http://www.nat-hazards-earth-syst-sci.net/3/693/2003/.

ISRM (International Society for Rock Mechanics): Rock Characterization, Testing and Monitoring-ISRM Suggested Methods, Pergamon Press, Oxford, 211 pp, 1981.

Jaboyedoff, M. and Labiouse, V.: Preliminary assessment of rockfall hazard based on GIS data, ISRM 2003 - Technology roadmap for rock mechanics, South African Institute of Mining and Metallurgy, 575-578, 2003.

Karacan, E. and Kasapoglu, K. E.: An investigation on the fractures and joints in the Ankara andesites, Yerbilimleri, (in Turkish), 13, 63-75, 1986.

Kasapoglu, K. E.: Ankara Kenti Zeminlerinin Jeoteknik Özellikleri ve Depremselligi, TMMOB Jeoloji Mühendisleri Odası Yayını, No, 54, Ankara, 2000.

Krause, J. P., Mock, R., and Gheorghe, A. V.: Assessment of risks from technical systems: integrating fuzzy logic into the Zurich Hazard Analysis method, Int. J. Environ. Pollut., 5, 2/3, 1995.

Matlab (6.5): The language of Technical Computing, Fuzzy Logic Toolbox, 2002.

Matterocking (2.0): Users's Guide, Open report, Quanterra, http: //www.quanterra.org, 24 p., 2002.

Negnevitsky, M.: Artificial Intelligence: a guide to intelligent systems, Addison-Vesley, Harlow, England, 2002.

Petje, U., Ribicic, M., and Mikos, M.: Computer simulation of stone falls and rockfalls, Acta geographica Slovenica, 45-2, 93120, 2005.

Resources Inventory Committee: Guidelines and standards for Terrain Mapping in British Columbia, Res. Inv. Ctee, Victoria, BC, Canada, 1996.

Ross, T. J.: Fuzzy Logic with Engineering Applications, Mc-GrawHill, New Mexico, 1995.

Surfer (Ver. 8): Golden Software Inc., Colarado, USA, 2002.

Wieczorek, G. F., Morrissey, M. M., Iovine, G., and Godt, J.: Rockfall Hazards in the Yosemite Valley, U.S. Geological Survey Open-file report 98-467, scale 1:12 000, 7, 1998.

Zadeh, L. A.: Fuzzy sets, Information and Control, 8, 338-353, 1965.

Zadeh, L. A.: Outline of a new approach to the analysis of complex systems and decision processes, IEEE Transactions on Systems, Man and Cybernetics, SMC-3, 28-44, 1973. 